\title{
Introduction: engaged scholarship for non-capitalist political ecologies
}

\author{
Brian J. Burke and Boone Shear ${ }^{1}$ \\ University of Georgia, USA \\ University of Massachusetts Amherst, USA
}

\begin{abstract}
The articles in this special section, by offering ethnographically grounded reflections on diverse strains of economic activism, begin to articulate a non-capitalocentric political ecology that we think can help scholaractivists politicize, reimagine, and recreate socio-ecological relations. In this introductory article, we offer a useful vision of how scholar-activists can engage with and support more just and sustainable ways of organizing human-human and human-environment relations. Specifically, we argue that engaged researchers can significantly contribute to a meaningful "ecological revolution" by (1) examining the tremendously diverse, already-existing experiments with other ways of being in the world, (2) helping to develop alternative visions, analyses, narratives, and desires that can move people to desire and adopt those ways of being, and (3) actively supporting and constructing economies and ecologies with alternative ethical orientations. Each article in this collection attempts one or more of these goals, and this introductory article provides a conceptual grounding for these ethnographic studies and a synthesis of some of their primary contributions. We begin by describing why critique is analytically and politically inadequate and explain why we think a non-capitalocentric ontology offers an essential complement for engaged scholarship. We then turn to the work of J.K. Gibson-Graham and the Community Economies Collective in order to explain how ideas of overdetermination, diverse economies, and performativity better equip the field of political ecology to contribute to alternative futures. And finally, we discuss how the articles in this volume reconceptualize values, politics, and scale in a manner that illuminates our scholarly and activist efforts.
\end{abstract}

Keywords: non-capitalism, political ecology, alternative economies, capitalism, scale, values, politics, Gibson-Graham

\section{Résumé}

Les articles de cette section spéciale offrent des réflexions ethnographiques sur diverses souches de l'activisme économique. Ils commencent à articuler une écologie politique «non - capitalocentrique» que nous pensons peut aider universitaires militants politiser, réinventer, et de recréer les relations socio-écologiques. Dans cette introduction aux articles, nous vous offrons une vision utile de la façon des chercheurs-militants peuvent s'engager et soutenir les modes d'organisation des relations humaines-humain et humainenvironnement plus justes et durables. Plus précisément, nous soutenons que les chercheurs engagés peuvent contribuer de manière significative à une «révolution écologique» significative par (1) l'examen des diverses expériences, déjà existants avec d'autres manières d'être dans le monde, (2) d'aider à développer des visions alternatives, analyses, récits, et les désirs qui peuvent se déplacer les gens à désirer et d'adopter ces manières d'être, et (3) de soutenir activement et de construire des économies et écologies des orientations éthiques alternatives. Chaque article de cette collection tente un ou plusieurs de ces objectifs, et cet article

\footnotetext{
${ }^{1}$ Dr. Brian J. Burke, post-doctoral research associate, Coweeta Long Term Ecological Research (LTER) Program and the Coweeta Listening Project, University of Georgia, USA. Email: bjburke "at" uga.edu. His research examines and supports grassroots mobilization to change political-ecological relationships through initiatives such as cooperatives, alternative economies, ecovillages, and public engagement with environmental science. Boone Shear, PhD candidate at the University of Massachusetts Amherst, USA, interested in community responses to social and economic restructuring, economic subjectivity, alternative and community economies, and activist anthropology Email: bshear "at" anthro.umass.edu. His dissertation research, supported by a Wenner-Gren Foundation Dissertation Fieldwork Grant, explores the cultural politics of economy in relation to green economy discourse in Massachusetts. Both authors would like to thank the contributors to this special section, the participants in the Alternative and Non-Capitalist Political Ecologies Track at the Society for Applied Anthropology's 2012 Annual Meetings, and the supportive commentary of JPE editors and reviewers. Boone would like to thank his excellent daughter, Rose. This is the introductory paper in Burke, B.J. and B.W. Shear (eds.) 2014. "Non-capitalist political ecologies", special section of the Journal of Political Ecology 21: $127-221$
} 
d'introduction fournit une base conceptuelle pour ces études ethnographiques et une synthèse de certains de leurs principales contributions. Nous commençons par décrire pourquoi la critique «seule» est analytiquement et politiquement inadéquate et expliquer pourquoi nous pensons une «ontologie non capitalocentrique» offre un complément essentiel pour l'érudition engagée. Nous passons ensuite aux travaux de J.K. Gibson-Graham et les économies communautaires collectives afin d'expliquer comment les idées de surdétermination, diverses économies, et performativité mieux peut équiper le domaine de l'écologie politique pour contribuer à d'autres avenirs. Et enfin, nous discutons de la façon dont les articles repenser les valeurs, la politique, et de l'ampleur d'une manière qui appuie nos efforts scientifiques et activistes.

Mots-clés: non-capitalisme, l'écologie politique, les économies alternatives, le capitalisme, l'échelle des valeurs, la politique, Gibson - Graham

\section{Resumen}

Los ensayos en este número especial, ofreciendo reflexiones fundamentadas en estudios etnográficos sobre diversos esfuerzos de activismo económico, comienzan a articular una política ecológica no-capitalocéntrica que pensamos puede ayudar a los académicos-activistas a politizar, reimaginar, y recrear relaciones socioecológicas. En este ensayo introductorio, ofrecemos una visión útil de cómo académicos-activistas pueden comprometerse con y apoyar más formas justas y sustentables de organización de relaciones humano-humano y humano-ambiente. Específicamente, argumentamos que investigadores comprometidos pueden contribuir significantemente a una valiosa "revolución ecológica" (1) examinando los tremendamente diversos, yaexistentes experimentos con otras maneras de ser en el mundo, (2) ayudando a desarrollar visiones, análisis, narrativas, $\mathrm{y}$ anhelos alternativos que puedan llevar a la gente a anhelar y adoptar esas otras maneras de ser, y (3) activamente apoyando y construyendo economías y ecologías con orientaciones éticas alternativas. Cada ensayo de esta colección busca uno o más de estos objetivos, y este ensayo introductorio provee una base conceptual para estos estudios etnográficos y una síntesis de algunas de sus principales contribuciones. Comenzamos describiendo por qué la crítica es analítica y políticamente inadecuada, y explicando por qué nosotros pensamos que una ontología no-capitalocéntrica ofrece un complemento esencial para académicos comprometidos. Después presentamos el trabajo de J.K. Gibson-Graham y el Colectivo de Economías Comunitarias (Community Economies Collective) con el fin de explicar cómo ideas de sobredeterminación, economías diversas, y performatividad equipan mejor el campo de la ecología política para contribuir así a futuros alternativos. Y finalmente, discutimos cómo los artículos en este volumen reconceptualizan valor, política, y escala en una manera que ilumina nuestros esfuerzos académicos y activistas.

Palabras clave: no-capitalismo, ecología política, economías alternativas, escala, valores, política, GibsonGraham

\section{Introduction}

We live today at the intersection of two great crises: an economic crisis that has brought severe social dislocations, growing inequalities, and violence, and an ecological crisis that has destroyed the natural resources that sustain us and the ecosystems within which we and millions of other species dwell. These inextricably intertwined crises shape the everyday lives of people around the world, including our neighbors and our own families. ${ }^{2}$ We see the crises in the desperate but determined faces of farmers who sit down and light themselves on fire while governments and corporations debate the future of agriculture. We see the crises in the ecological and social devastation brought on by more intensive fossil fuel extraction and use, the difficulties of adapting to a changing climate, and the challenges of managing nuclear energy and waste. We see the crises in the gendered and racialized divisions of labor, uneven distribution of economic benefits and environmental toxins, and - in response - the growth of environmental and economic justice movements. We see them in the fate of the hundreds of thousands of families left homeless by the current economic crisis,

\footnotetext{
${ }^{2}$ By violence we are referring to the social, cultural and structural violence on individual bodies (Farmer 1996; Nguyen and Peschard 2003; Yates 2008), and the social-symbolic processes that naturalize these types of violence (Shear and Lyon-Callo 2013), as well as the site-specific, locally contingent conjunctures of natural resource control and political economies of violence (Peluso and Watts 2001).
} 
families who paid in to the dream of progress and prosperity and in the process provided capital to the world's biggest banks. These same families unwittingly helped to underwrite the expulsion of people from their ancestral lands for the sake of global mineral exploration, financed the construction of factories to absorb the masses of rural peasants left landless by the "rational exploitation" of natural resources and the enclosure of the global commons of agricultural diversity, and supported the growth-obsessed speculation that would ultimately return to haunt them.

These crises are not unhappy accidents of an economy that is simply out of balance, nor do they result from inadequate or excessive regulation or the unjust actions of a few bad apples who let greed get the best of them. Rather, they result from the social relations that define our lives, relations that produce and are produced by particular ways of understanding, knowing, and being in relation to an economy and ecology that we have come to see as natural and inevitable.

Antonio Gramsci (1971) reminds us however that crises are not only destructive; they destabilize socio-economic relations and cultural narratives in ways that can open up new symbolic and social possibilities and thus help to support new desires and revolutionary politics. Today's crises therefore present opportunities to move beyond the conventional "solutions" of coping and accommodating, managing and adapting, resisting and reforming. They create space for social and economic experimentation, new political alliances, new cultural narratives, and alternative social and socio-ecological relations. In short, these crises may give rise to new modes of being in the world that can move us toward a more sustainable and egalitarian future.

But how are these new modes of being created and how can activist scholars engage with and support them? These are the questions that inspire the political ecological inquiries collected in this special section. These articles examine how people around the world are creating new economies rooted in cultural values other than efficiency and profit-seeking, identities beyond rational individualism, social relations other than competition and exploitation, and ecological relations other than objectification, disenchantment, commodification, and domination. They illustrate the cultural work through which activists are subjecting human-human and human-environment relations to critical scrutiny and creative reconstruction. And they analyze the new spaces, structures, and institutions that enable people to survive and thrive through less exploitative and more sustainable relations.

These articles, taken together, begin to articulate a non-capitalocentric political ecology that we think can help scholar-activists politicize, reimagine, and recreate socio-ecological relations. We agree with Foster (2009) and others that a proper "ecological revolution" necessarily involves political-economic transformations that move us away from capitalist production and exchange. This political project will likely draw on research about capitalist exploitation and destruction to support social movements that oppose oppression and exploitation, ecological degradation, and environmental injustice (Ferguson 2010). However, following Gibson-Graham (1996, 2006), we argue that critical analyses of an integrated and cohesive capitalist system do not simply reflect an objectively true, external reality; they also actively construct a worldview (and a world) that limits our political imaginations and sense of agency. A political ecology to advance non-capitalist socio-ecological relations must, therefore, involve more than opposition and critique; it must build on already-existing non-capitalist practices in order to foment new desires and foster new political possibilities (see also Burke and Shear 2013). A key part of this politics is learning to see and desire noncapitalism in many places and at many scales and to understand these as part of a revolutionary politics. Building non-capitalism requires moving beyond reformism and resistance, toward a non-capitalocentric politics that projects possibilities and desires beyond what can be conventionally imagined as feasible. It moves beyond what Alain Badiou refers to as the "'state of the situation,' the system of constraints that limits the possibility of possibility..." (Badiou 2010: 7).

Engaged researchers can significantly contribute to an ecological revolution by: 
(1) examining the tremendously diverse, already-existing experiments with other ways of being in the world,

(2) helping to develop alternative visions, analyses, narratives, and desires that can move people to adopt those ways of being, and

(3) actively supporting and constructing economies and ecologies with alternative ethical orientations.

Each of the articles collected here models how academics can contribute to alternative socio-ecological futures, exploring cultural and political work from an ontological perspective that, at least partially, decenters and denaturalizes capitalist relations of production.

In this introduction, we frame the articles by more clearly defining what we mean by a non-capitalist political ecology, which we see not only as an analytical framework, but also as a worldview and ethos, a map of the world and a map for our action in the world. ${ }^{3}$ We begin by briefly discussing the significance of adopting this perspective-why does it matter if we are capitalocentric or not? We then turn to the work of J.K. Gibson-Graham and the Community Economies Collective in order to explain how ideas of overdetermination, diverse economies, and performativity better equip the field of political ecology to contribute to alternative futures. And finally, we discuss how the articles in this volume reconceptualize values, politics, and scale in a manner that illuminates our scholarly and activist efforts.

\section{To describe the world and to change it: on the politics of knowledge and the role of academics}

To be clear, the underlying foundations of our argument emerge from the Gramscian proposition that intellectual and cultural work is central to politics, as well as from constructivist theories that language and ideas affect material relations. Indeed, numerous scholars in political ecology, cultural studies, and science studies have clearly demonstrated how the discursive and symbolic framing of a situation produces material, socio-ecological relations. In this sense, to describe the world in a compelling way is to change it, and to change the world requires compelling new descriptions.

A classic example of this scholarship is Piers Blaikie's work on the socio-economic and political effects of scientific understandings of erosion. In a conceptual innovation that now seems commonplace, Blaikie argued that environmental science does not proceed through the neutral application of objective practices, but rather entails the selection of particular analytical frames out of a larger universe of possibilities, each of which could derive from different values and result in different justice outcomes (Blaikie and Brookfield 1987). In Forsyth's words, Blaikie "tried to show that changing these values, or diversifying the social framings of environmental analysis, may result in more socially just environmental knowledge and policy" (Forsyth 2008: 757).

Many authors have followed Blaikie's lead, whether explicitly or implicitly, to examine "the politics of environmental epistemology" in a range of contexts (Forsyth 2008: 756). For example, Greenberg (1997) reflected on structural adjustment policies in the Dominican Republic to show how differences in data sources and a priori assumptions across disciplines can result in very different evaluations of their ecological and economic effects. Davis (1999) and Swyngedouw (2011) have analyzed how the "crisis talk" and apocalyptic metaphors common in environmental campaigns affect popular imaginings of the environment and activism. Working at a different scale, Lee and Roth (2001) conducted a long-term ethnography of environmental activism around stream health, carefully illustrating how different images of nature are created and mobilized in order to shape the types of environmental policies that are thinkable and the types of community groups

\footnotetext{
${ }^{3}$ Geertz (1973) used the terms "worldview"/"ethos" and "model of"/"model for" to describe what makes religions meaningful. While we certainly don't think of a non-capitalocentric political ecology as a religion, we find the terms useful for capturing the two-fold nature of this theoretical stance: it is a way of imagining the world that suggests a particular way of acting in the world.
} 
that form to achieve them. What these scholars show us is that political possibilities are circumscribed and constrained by the limits of our symbolic worlds.

Escobar takes this constructivist argument even further, arguing that what we are talking about is both "ontological and epistemological transformation" (Escobar 1999: 2). Understood and represented differently, nature becomes different (at least for many practical purposes) and therefore contributes to and sustains different ways of organizing labor, technology, and society for production, exploitation, and politics. Butand this is crucial- -...the cultural and biological resources for collectively inventing natures... are unevenly distributed" (Escobar 1999: 2), hence the importance of political ecological studies of marginalization and unevenness. What is perhaps most salient about these arguments, for our purposes, is that they suggest that we as academics should understand ourselves as intrinsically in the business of not simply analyzing and uncovering but actually creating the social-symbolic order. Escobar thus urges political ecologists to "situate ourselves in the circuits of power-knowledge" and consider how we can "contribute to the... politics of nature production by subaltern or other groups and... to the elaboration of alternative ecological and economic proposals" (1999: 15). Similarly, Blaikie sought to reconstruct a more just and inclusive version of environmental science "by making the normative connections between social values and different knowledge claims transparent, and by prioritizing the needs of vulnerable people when building different explanations" (Forsyth 2008: 760).

Slavoj Zizek (2004, 2007) deepens these insights in his discussions of former US Secretary of Defense Donald Rumsfeld's statement that the "unknown unknowns" were the US's biggest concern in Iraq. In response Zizek says the main dangers were really the "unknown knowns, the disavowed beliefs and suppositions that we are not even aware of adhering to ourselves" (Zizek 2007: n.p.). "In the case of ecology," Zizek continues, "these disavowed beliefs and suppositions are the ones which prevent us from really believing in the possibility of catastrophe and they combine with the 'unknown unknowns'. The situation is like that of the blind spot in our visual field: we do not see the gap, the picture appears continuous." For Zizek, an essential step in a politics that can adequately address ecological crisis is the intellectual task of "unearthing" all of the ways in which these background beliefs and practices—culture, if you will—attach us to our current course of social action even when we know, on some level, that this course is producing ecological crisis. While Zizek suggests that we dig up our most destructive behaviors, we contend that our project should also involve excavating the symbolic, libidinal, and material grounds for egalitarian and sustainable worlds.

\section{From capitalocentrism to a non-capitalist ontology}

J.K. Gibson-Graham, whose work inspires much of our intellectual and political approach, are conducting a similar analysis to those described above, but focused on the politics of economic epistemology and ontology. Just as ways of representing a stream might affect the types of conservation we imagine and pursue, Gibson-Graham ask how our economic imaginaries shape our politics. Writing in the mid-1990s, after "the end of history," when authoritarian communism had fallen and neoliberal capitalism appeared ascendant, Gibson-Graham found a remarkably homogenous political climate within the academic discipline of geography. "In the mid-1990s," they wrote:

...there was no conversation [about alternatives to capitalism], and seemingly no community to interact with.... A new regime of accumulation appeared to be consolidating the hegemony of capitalist relations and all that we could hope for was a more efficient or humane capitalism—flexible specialization or Blair's third way. (Gibson-Graham 2008: 614)

The dominance and inevitability of capitalism appeared as self-evident in geography, as in the rest of the academy and in the broader political field. Capitalism's seeming dominance and intractability is produced in part by the way that we talk and think about the economy; it's a problem of our economic imagination. It is taken for granted that the economy is dominantly capitalist, that the economy is global, and that this global capitalist economy holds together as a system or structure. Gibson-Graham describe this discursive 
production and enclosure as capitalocentrism (1996, 2006). Geographer and Community Economies Collective member Janelle Cornwell explains how the political spectrum is contained and constrained by capitalocentric thinking:

On the right capitalism is the bearer of democracy, modernity, and technological innovation, while the left represents capitalism as a self reproducing perpetrator of destruction, a colonizer and penetrator of non-capitalist spaces. Gibson-Graham call these perspectives 'capitalocentric' because 'capitalism' is the master term that gives everything its identity and meaning. Every economic practice, relationship, and effect (good and bad) is related back to the same central driver: capitalism (and its consequences or opportunities). Capitalocentric thinking is problematic because it obscures economic diversity and thus limits the possibility for noncapitalist interventions, innovations, and experiments. (Cornwell 2013)

Of course, anthropologists and other scholars have shown-and common sense tells us-that economic difference exists, that economic practices are not inevitable but contingent, and that there continues to be great resistance to capitalism (Martinez-Alier 2014; Trainer 2005; Wolf 1982). But in a largely capitalocentric imaginary, alternatives and resistance to capitalism are contained within and must answer to the global capitalist system. Whether we like capitalism, or want to modify it, or we seek to oppose it-in every case our identities and our political acts are necessarily forged in relation to capitalism, in relation to "reality". In this imaginary, our hopes for revolutionary transformation have a difficult time being revolutionary precisely because there are few symbolic resources to marshal in envisioning a horizon beyond capitalism.

As a way out of this intellectual-political morass and towards a project of possibility, Gibson-Graham suggest that we acknowledge that our scholarship helps construct economic reality, and they propose that we perform a politically empowering construction. As tools, they offer an anti-essentialist reworking of the economy advanced via new economic imaginaries, languages, and identities oriented toward diverse community economies. Rather than understanding the economy as an unyielding capitalist system or structure, we can choose to represent and engage the economy as a diverse array of economic relations and practices "scattered across a landscape"-different arrangements of production, exchange, surplus appropriation, ownership, and so-on (Figure 1).

In this diverse economies frame, "capitalism" is reduced from an impenetrable, all-powerful system, more precisely to a capitalist firm producing for a capitalist market; this is one relatively modest component of a broad and diverse economy that includes non-capitalist relations and enterprises. As illustrated in Figure 1 , these non-capitalist relations of production, exchange, circulation, and ownership can take many different forms, and they are not necessarily more ethical or liberating than capitalism. This is a critical point. The diverse economies perspective does not simply posit a new, liberatory structure in place of an old, exploitative capitalist structure, but rather offers us the opportunity to identify, analyze, and deliberate about the distinct socio-ecological consequences of different types of economic relations.

In addition, each aspect of the diverse economy is understood as overdetermined in place. Social arrangements, institutions, and subjects are not the result of inevitable, structuring logics, but are constituted by the effects of all other entities, all at once. ${ }^{4}$ No entity or process is a singular determinate factor in another; nothing has an inescapable essence. Each entity—and indeed each human subject—is constituted by and is constituting all others; it exists in flux, as a process that is "pushed and pulled" (Resnick and Wolff 2013: 342) in divergent directions. Thus, relationships, practices, and initiatives all become sites of possibility, neither canvasses for an unconstrained free will, nor systematically pre-formed. Capitalist sites and processes become open to transformation and engagement, and non-capitalist sites and processes must be granted their own political and ontological weight.

${ }^{4}$ See Resnick and Wolff's elaboration of Althusser (1987). 
Through the theoretical lens of overdetermination, a capitalist site is an irreducible specificity. We may no more assume that a capitalist firm is interested in maximizing profits or exploitation than we may assume that an individual woman wants to bear and raise children, or that an American is interested in making money. When we refer to an economy-wide imperative of capital accumulation, we stand on the same unsafe ground (in the context of the anti-essentialist presumption of overdetermination) that we tread on when we refer to a maternal instinct or a human drive to acquisition. (Gibson-Graham 1996: 16)

\begin{tabular}{|c|c|c|}
\hline TRANSACTIONS & LABOR & ENTERPRISE \\
\hline Market & Wage & Capitalist \\
\hline Alternative Market & Alternative Paid & Alternative Capitalist \\
Sale of public goods & Self-employed & State enterprise \\
Ethical 'fair-trade' markets & Cooperative & Green capitalist \\
Local trading systems & Indentured & Socially responsible firm \\
Alternative currencies & Reciprocal labor & Non-profit \\
Underground market & In kind & \\
Co-op exchange & Work for welfare & \\
Barter & & Non-Capitalist \\
Informal market & Unpaid & Communal \\
Non-Market & Housework & Independent \\
Household flows & Family care & Feudal \\
Gift giving & Neighborhood work & Slave \\
Indigenous exchange & Volunteer & \\
State allocations & & \\
Gleaning, gathering & & \\
Hunting, fishing & & \\
Theft, poaching & & \\
\hline
\end{tabular}

Figure 1: The diverse economy (Cameron 2007, adapted from Gibson-Graham 2006: 71).

This theoretical package produces new effects, new affects, and new desires for social analysis and political struggle. For the latter, seeing the economy as fundamentally heterogeneous and overdetermined expands politics beyond resistance to also include constitutive, productive actions that include locating, creating, and organizing around spaces where collective, ethical economic decision making is encouragedfor example, around the collective appropriation of surplus found in worker cooperatives, or around the ethical deliberation found in alternative markets like fair trade, or around the expansion of the commons, and so on. For the former, an ontology that validates non-capitalism provokes us to move away from intellectual habits and desires that anchor us to critique and the analysis of social reproduction-i.e. seeking to understand all the ways that ideas, movements, and enterprises are always already doomed to failure, cooptation, or triviality. Instead, we are urged to locate and theorize the production of actually existing non-capitalism, as well as spaces for potential transformation, and to look for the emergence of non-capitalist desires, beliefs, practices, and movements. It is this cataloging and cultivating of economic difference-and especially of those non-capitalist relationships though which people can be encouraged to act ethically-that lays the groundwork for a post-capitalist politics in which communities might be able to begin to collectively make ethical economic decisions (Gibson-Graham et. al. 2013). 
Before turning to Gibson-Graham's ideas of performativity or activist scholarship, it is worth contextualizing these core ideas of capitalocentrism, diverse economies, and overdetermination within the work of anthropological political economists. Anthropologists have been keenly aware that capitalism did not expand into an unformed world that it could mold in its own image. Our studies of capitalism have just as often been studies of non-capitalisms and the dialectical relationships among diverse capitalisms and noncapitalisms. Eric Wolf, for example, was particularly influential in charting an anthropological approach that understands diverse capitalisms as emerging from articulations between capitalist and non-capitalist economic systems, with special attention to the ways that cultural forms mediate these social relations in particular places (Roseberry 1989: 162; Wolf 1982).

Greenberg's research on the persistence of indigenous non-capitalist institutions (Greenberg 1981) and syncretic notion of money (Greenberg 1995) builds on this tradition. By demonstrating how people pursue economic and social goals through mediating institutions that are imbued with culturally-specific meaning, he shows how "global" capital and apparently neutral abstractions like money are localized, adopting unique properties, providing different opportunities, and prompting diverse consequences based on local acceptance, accommodation, and resistance. His findings support Roseberry's belief that "the local is global... but the global can only be understood as always and necessarily local" (1998: 521). Robben (1989) offers a slightly different way of studying economic diversity. Examining economic change in a Brazilian fishing village, he observes that modes of production are certainly material, but they are also as part of conceptual and normative models of household behavior, social relations, masculinity, community belonging, and aspirations for autonomy. When new possible modes of production destabilize these community norms, people work to create a better fit between their everyday experiences and their worldviews. This initiates a process of experimentation, negotiation, and change that cannot be predicted by capitalist logics or relations. In Greenberg and Robben, then, we see that capitalism and non-capitalism are deeply intertwined and mutually shaping, that they are constructed and maintained through some of the same social relations and cultural dynamics, and that they take different forms across space and time.

Finally, Donham (1999) extends the insights of Wolf and theorists of articulation of modes of production like Foster-Carter by bringing questions of scale, power, causality, and economic diversity together in a particularly nuanced way. Critiquing structural Marxists' and world systems theorists' ideas that capitalist expansion was inevitable, he wrote, "If everything is capitalist, there are no other models to capture the reality of local political economies that look very different from the wider system in which they are embedded" (Donham 1999: 162). He also casts doubt on the belief that capitalism "needs" certain things or is driven by particular logics (Donham 1999: 209); the conditions and consequences of capitalism are historical questions and not given 'essences.' Finally, he argues against the idea of modes of production, asserting that to specify a mode of production is to impose an abstract model, assert its dominance, and functionally subordinate other styles of production to the dominant one. Making this analytical move-declaring which types of economic action are dominant-depends on the theorist's definition of what temporal and spatial scale will be privileged and which will be ignored. Instead, Donham (2001) argues that historical analysis is necessary in order to see the contingent and contextually defined historical processes that give rise to particular forms of capitalism, non-capitalism, and hegemony.

These anthropologists take us closer to the anti-essentialist, post-structuralist position of GibsonGraham, but Gibson-Graham move a step beyond Donham. Where Donham argues that a language of modes of production and discrete economic systems can never fully capture the complexity of economic relations, Gibson-Graham insist that such systems therefore cannot be treated as if they exist in some pre-cognitive, prediscursive, pre-performative, or pre-social reality. To do so is analytically problematic and politically limiting. Motivated to not only understand capitalism but also to understand and support non-capitalism, GibsonGraham argue that political economic analysis must involve a fracturing of abstractions in order to capture the full diversity of productive systems and class relations that operate in distinct spaces and scales. Such an analysis may be more faithful to Marxism than many readers believe, for as Donham concludes, "It is often thought that Marxism emphasizes determinism. The reverse is also true. For the final object of historical materialism, that for which the analysis of causes is only a prerequisite, is locating contingency-and thus being able to act upon it" (1999: 212). 
This leads us to performativity, the aspect of Gibson-Graham's project that is perhaps most challenging to conventions in social science (see also Healy 2014, this special section). Despite their differences, positivist, interpretive, and critical approaches often remain committed to the work of discovering and uncovering the way that things really are, what is really happening, and what people really believe (Cameron et al. 2010; Gibson-Graham 2008). This shared realist epistemology can work to "cement an emerging world in place, rather than readying it for transformation" (Gibson-Graham 2008: 614); research that attempts to understand and describe what already exists, even with the intention of changing it, can have unintended performative effects.

Turning this problem on its head, Gibson-Graham embrace a performative approach in which the goal "...is still to understand the world in order to change it, but with a poststructuralist twist-to change our understanding is to change the world, in small and sometimes major ways..." (Gibson-Graham 2008 citing Law and Urry, 2004: 391). David Stark nicely illustrates the implications of performativity:

If you show someone a map and say 'this is how people get from Point A to Point $\mathrm{B}$, ' the statement is performative when it creates the behavior it describes. In this case, a path gets worn in the ground between Point A and Point B. Thus, performative statements don't reflect reality (as in the declarative statement 'this is a pen'), but intervene in it. Performative language is an engine, not a camera. A model becomes performative when its use increases its predictive capabilities. (Stark, cited in Harrington 2010)

Gibson-Graham contend that much of social theory, by virtue of its capitalocentrism, has had the perverse effect of creating a path from the present to a capitalist future. Our hope for a non-capitalist, noncapitalocentric political ecology, is to engage in and help perform a multiplicity of other paths that lead to other futures.

We see in Gibson-Graham's work three registers of performativity. The first is the performative/political importance of changing our own ontology and stance towards the economy. By 'stance' we mean "...an ideological-emotional orientation towards an issue that reflects and influences our thinking and actions" (Shear 2014, and especially see Gibson-Graham 2006: 1-11). This is no small task. For many critical academics and activists, our identities are bound to an investment in critiquing and fighting against the overreaching, unyielding dominance of a capitalist system. But taking a leap of faith towards this ontological reframing is critically important; it allows us to adopt a stance of possibility rather than only critique, look for transformation rather than enclosure, and tells us that we can't know ahead of time that alternatives are "doomed to fail[ure]" (Gibson-Graham 2006: 8). The diverse economies framework that Gibson-Graham propose can be thought of as a living document, one possible way to conceptualize non-capitalocentric economies. The authors in this special section adopt different aspects of Gibson-Graham's work and mobilize their theory in different ways, but all ally themselves with a common ontological beginning, situating their work with an intentional openness and active movement towards possibility.

Second, is the performativity enacted through textual representation - the non-capitalist world that we can show as possible and already here through our analyses and stories of the struggles, experiments, and movements to create new worlds that researchers are witness to and participate in? Each article in this special section discusses an engagement with on the ground movements and politics that are immersed in noncapitalist practices and values. Understanding that our texts are doing more than capturing an authentic or true aspect of reality - understanding that our writing is, in fact, making culture (Clifford and Marcus 1986) these articles endeavor to show economic difference, not at the mercy of global capital, but as living economies of non-capitalism in their own right that can offer footholds and spaces for further expansion and political struggle.

Finally there is the level of the performative intervention of the diverse economies model itself. It is here that we find ethnographic investigation to be particularly valuable in merging performative and realist approaches. In contrast to engaged research that seeks to create economic possibility and alternative economies through relatively bounded experiments during research encounters, authors in these articles look to understand, reveal, and complicate the ways in which social actors imagine and enact non-capitalist values 
and practices in relation to on-the-ground movements, even as they struggle alongside them. We contend that the long term, intimate nature of ethnographic work can help to show areas of contradiction as well as exciting new possibilities for non-capitalist politics in different social settings.

\section{Analyzing and performing non-capitalist political ecologies: an introduction to this volume}

In this vein, we have assembled articles that illustrate how elements of Gibson-Graham's framework can be mobilized to perform new economies and to powerfully analyze contemporary socio-ecological relations and politics. Two of our articles focus on consumer-based activism via U.S. fair trade activism (Lyon 2014) and Italian solidarity purchasing groups (Grasseni 2014). By distancing themselves from the familiar capitalocentric critique of consumer activism as a neoliberal, individualizing distraction from radical politics, Lyon and Grasseni are able to appreciate the broader political and social consequences of these movements. Indeed, both show that fair trade and GAS movements go beyond consumption to pursue and achieve a more fundamental re-configuration of food/technology/capital/people. Participants are politicizing the social relations of production and exploitation that underlie commodities and developing institutions to convert political critique into collective action.

Johnson's paper (2014) examines a non-capitalist, community intervention against the impacts of capitalist production and commodity exchange, focusing on activism by Arctic people who have suffered tremendously from a disembedded system of production that makes it easy to ignore distant social and ecological effects. In the case that she describes, organizing against persistent organic pollutants requires a move to the international scale, where Inuit activists are at a distinct disadvantage vis-à-vis other interested parties. In a very nice example of anthropological holism, Johnson shows how Inuit knowledge and affect emerge from particular socio-environmental relations, which are themselves forged through non-capitalist subsistence practices. Inuit activists are able to change the dynamics of international political deliberation through the simple act of gifting, which grants a permanent and symbolically powerful presence to those activists, their home environment, and the families and communities created through ongoing economic transactions across the human-nature divide.

Shear's paper (2014) brings us to the construction of non-capitalist relations in the rust belt of the U.S. He explores how grassroots activists in Massachusetts are engaging with the meaning of the green economy and generating alternative economic visions and desires that touch not only on consumption, but also production, ownership, and distribution. "The green economy," he writes, "is a contingent, undetermined economic space full of circulating desires, ideologies and fantasies, and a full range of capitalist and noncapitalist relations and practices." (Shear 2014: 206). Shear draws on the work of Gibson-Graham and Lacanian psychoanalytic theorists to examine how different economic imaginaries and desires create openings for the construction of non-capitalist relationships, initiatives, and enterprises. Where Johnson's paper examines the ongoing political role of what might be termed "traditional" forms of embedded non-capitalism, Shear details efforts to intervene in politics through forms of non-capitalism designed around collectivelynegotiated ethics.

Finally, Healy (2014) brings us back to engaged scholarship and the role of intellectuals by detailing how the Community Economies Collective has struggled to advance scholarship on non-capitalist political ecologies while simultaneously supporting experiments with non-capitalism around the world and embodying non-capitalist values themselves. While many scholars have reflected on the ethics and practice of activist research, Healy's paper is particularly valuable for its original theoretical framing and because he details the additional struggles of conducting action research in a radically non-hegemonic vein (cf. Day 2005). Noncapitalist or post-capitalist action research thrusts academic collaborators into the uncomfortable position of deep uncertainty, because it demands that we distance ourselves not only from a common enemy (capitalism) but also from familiar ways of imagining the world (and our enemies). Through several examples drawn from the Community Economies Collective, Healy shows how this starting point of uncertainty or surprise allows difference (economic difference, ecological difference, ethical difference) to provoke ethical-political deliberation about economies and ecologies. Beyond simply demonstrating that other worlds are possible, we 
think that these articles address some of the most important questions for a non-capitalist political ecologyquestions about the development and articulation of new values, ethics, and knowledge; the process of permanent politics; the construction of new places and communities; and the ways that these processes and politics vary and move across scales.

\section{Values}

All of the articles in this collection-and all of the political movements that they represent-take values as a central concern. How are people across the world turning their discontent with the status quo into alternative sets of values, and how are they building the material, social, and cultural conditions that enable them to enact these values more effectively? Many grassroots movements and initiatives are seeking not only concrete material or political goals, but also a fundamental reformulation of the ethical underpinnings of modern society, and politics is increasingly taking the nature of the economy itself as an object of struggle. We believe that a close examination of these types of social movements and initiatives is essential if social scientists are to understand, represent, and support the construction of a more egalitarian and sustainable future.

In this political terrain, we see three crucial intellectual-political tasks:

(1) to examine how these alternative values and counter- or alter- modernities emerge,

(2) to examine the social and socio-ecological relations that result from these different visions, and

(3) to use our scholarship as a form of cultural and social/material politics that makes visible, creates, and supports non-capitalism and thereby brings it into the field of possibility.

Political ecology infuses these tasks with increased depth by forcing us to ask who is involved in the development and realization of these values, whose considerations are included (and why, when and how) and whose are excluded, and also by forcing us to consider how the non-human world figures into these processes as both driver and product.

With regard to values, there are two lessons in these articles that we find particularly provocative. First, Lyon, Grasseni, and Shear show that people increasingly see the economy as a fundamentally ethical sphere of socio-ecological relations, and that framing the economy in this way demands a focus on democratic process. For this reason, the Fair Trade and GAS movements foreground transparency as a core principle necessary for effective collective deliberation and action. In the case of these consumer movements, transparency involves, more than anything, the de-fetishization of commodities so that social and environmental injustices are no longer buried in the forgotten "secret life of things" but rather come to the fore and provide a referent for ethical consumption. Interestingly, activists in both movements have grown suspicious of de-fetishization through certification programs and they are insisting instead on a re-scaling of the economy. The result is a different type of spatial fix (Harvey 2003), what we might call an ethical-spatial fix or a spatial fix for non-capitalism: ethical concern requires that consumers lift the veil on commodities by proactively connecting to the sites at which they are produced, and that they re-negotiate and re-construct the landscapes and relations of production according to alternative ethics.

Shear takes these observations a step further, examining how values become deeply felt and motivating desires, and how the political import of values depends on the ways that they are refracted through particular ways of imagining the economy. Because he is able to tease apart the connections between desire, political imagination, and outcomes, his work is instructive for academics and activists. In a sense, all three of these movements are not only defetishizing commodities but also defetishizing justice and ethical behavior: they are refusing to accept the neatly packaged ethical "solutions" presented to them in favor of careful examination and deliberation, in the process upending the reformist promises of the Green Economy, the facile North/South distinctions often posed in the Fair Trade movement, and introducing issues of justice, vulnerability, and collaborative potential into the heartland of the global North as well. 
The second lesson about values is particularly evident in Johnson's article, which offers a particularly thought provoking discussion of how different sets of values and politics emerge and might be re-shaped. She argues that we cannot understand Inuit politics without understanding indigenous knowledge as content and process, that we cannot understand the process of indigenous knowledge without understanding its affective dimension, and that we cannot understand the affective dimension without seeing how it emerges from (and remains tied to) particular socio-environmental relations forged through non-capitalist subsistence practices. Hunting, for example, is not just killing an animal, but killing an animal through a particular set of individualcollective and individual-collective-environmental relationships, which are themselves constitutive of culture, values, and knowledge. As Johnson writes, thinking, affect, and politics are "not limited to the parameters of the human body, but rather [extend] outward through sensory perception into the environment itself" (2014: 166). Connection to the land is constitutive of each metabolic mode, and each person, and all politics. This discussion therefore draws our attention to much-ignored but potentially powerful sociomaterial/economic/environmental bases for activism and raises questions about how we might study and nurture these catalysts.

\section{Politics}

As Shear makes clear, though, these values are only one step toward non-capitalist political ecologies. We also need careful ethnographies of how activists convert values, hopes, visions, and imaginaries into political actions and alternative institutions. These articles provide that in a range of contexts, and they illustrate how important collectivities are in this process. Even in the case of fair trade-which has been critiqued as a form of individualized, consumer-based activism (Lyon 2011) — people are trying not only to defetishize commodities so they can make more ethical choices, but also to create new places, new and meaningful (significant and signified) localities that are characterized by dense webs of economic and affective inter-relations, and therefore new communities bound together by solidarity and mutuality. Lyon (2014:155), echoing Gibson-Graham, shows that:

...communities are forming around ethical deliberation about the economy and...pre-existing local economic politics and economic conditions (such as a retail environment dominated by corporate retailers) are forcing local fair trade movements to adopt broader political platforms that extend beyond the creation of ethical consumers and private, consumption-based activism.

Grasseni also shows how these communities, once formed, can weave themselves into broader networks of mutuality.

This brings us to a second point about politics. If we learn anything from the history of radical movements, it is that political zealotry tends to create schisms between potential allies. Many of the cases presented here, however, document how activists confront the moral ambiguities, ideological tensions, political differences, and strategic disagreements that constantly threaten counter-hegemonic solidarities. They are deep and necessary explorations of how activists might seek unity in the face of disagreement about anti-capitalist protest versus non-capitalist construction (Shear 2014), or of how Fair Traders concerned with international justice can build bridges with locavores focused on local ecologies and justice. In most of the articles collected here, activists turn difference into a source of strength rather than division; they organize an almost anarchic pluralism akin to the "non-hegemonic movements" that Day describes (Day 2005).

This is a particularly important consideration for allied academics, who make our living by writing and teaching, and are particularly rewarded for voicing critical perspectives. We hope that academic participation in these movements can help us learn how to frame our conclusions in ways that are critical and honest but that also build solidarity and a sense of agency. Too often our attempts to do so seem like airing people's dirty laundry rather than learning from one another, critiquing one another, pushing one another further, and advancing side by side (Chatterton, Hodkinson and Pickerill 2010). Deeper forms of academic-activist collaboration of the sort modeled by all of the authors in this collection offer promise. 


\section{Scale}

Finally, we argue that all of these lessons about alternative values and politics urge us to think carefully about scale. For many of the movements documented here, a key part of the values they are constructing involve re-scaling the boundaries of the moral universe: Lyon shows Fair Traders imagining their politics not only as a helping hand from North to South, but also as the creation of radical mutuality within the North; Grasseni shows consumers who are learning to weigh the needs of producers across their regions; Shear shows activists grappling with the challenge of creating a racially inclusive and politically effective alternative economies movement; Johnson shows Inuit activists insisting on the ethical consideration demanded by international toxicity; and Healy describes academics' experience subjecting themselves to analysis and politics while also forging collaborations beyond academia. Engaging broad constituencies in the re-scaling of ethical consideration is critical because, as Heynen (2003) showed very effectively, justice itself is scalar, sometimes with troubling trade-offs: urban reforestation programs driven by global climate considerations are likely to reproduce local injustices, whereas efforts to address local inequities in access to nature are likely to have little effect on global climate justice. If the scales of ethical action are defined without broad consideration for visible and less visible social and ecological consequences, we cannot adequately consider these dilemmas.

The contributions to this volume take these observations further, however, by examining how ethics and politics cross scales, and with what effects. Activism supporting alternative economies has often been criticized as a form of "militant particularism" that has relatively narrow impacts. These articles show (at least) three very important strengths in local politics that are not shared by broader-scale politics:

(1) semi-autonomous local organization seems to support more active participation in ethical deliberation and collective action than more universal approaches;

(2) the 'local' scale stands out more palpably as a site of construction and possibility;

(3) developing local economies and diverse strands of socio-ecological metabolism is a type of prefigurative politics that by its very nature challenges current conventions.

Finally, as Johnson's article (2014) demonstrates, economic logics and practices that emerge from the local can nevertheless jump scales, thereby calling into question the nature of the spatial relationship between the local and global.

Furthermore, in contrast to ethnographies and theory that endeavor to show the contradictions and troubling discursive effects of superficial political engagement (Lyon 2011; West 2010), these articles illustrate the cascading effect of politicization. We find, first of all, an individual's life cascades into other realms. Lyon and Grasseni, for example, show that individuals, once engaged in actions at one level, are likely to be more open to other forms of political action. Even individualized, private, consumer-based politics are often part of efforts to build broader ethico-political identities and to demonstrate or create broader social connections for materializing those identities. Secondly, we find that individual and local politics cascade outward to others. Sarah Lyon's suggestion that we think about activists as "persons-in-community" is particularly useful in this regard, as is Shear's story about the flow of inspiration and ideas between different solidarity and green economy projects. A key task for an optimistic critical anthropology is to trace how personal and local practices flow through social networks to take on a broader significance, even without coalescing into uniform movements. How do non-capitalist practices articulate to form non-capitalist economies? Following Grasseni, how do solidarity practices become solidarity economies? And following Johnson, how might thought/affect/politics cascade beyond the individual and beyond the merely human?

These articles therefore build on many of the key points made by Gibson-Graham. They also encourage followers of Gibson-Graham to treat the diverse economies language as a provisional ontology, and to be open to re-conceptualizing the diverse economies and community economy analytics according to 
local knowledge and experiences. ${ }^{5}$ In writing her paper, for example, Johnson was consistently hesitant to frame Inuit economics and sociality according to the diverse economies framework because this framework felt like an inappropriate imposition of knowledge/politics. In their writings, Gibson-Graham are careful to prioritize collective deliberation and to maintain community economies as an open, non-pre-defined category, even as they simultaneously work to position class-based exploitation as a central problematic.

Shear, too, suggests a productive addition to Gibson-Graham's proposals for enacting diverse economies and non-capitalism (1996). Gibson-Graham emphasize re-subjectification around diverse economies as a critical step in cultivating desires for non-capitalist values and practices. While embracing this point, Shear also shows that economic desires, values, and practices are not always concatenated, and that, in fact, attachments to non-capitalist desires might sometimes have the effect of closing off possibilities for the construction of politics that could build and support non-capitalist relations and structures. These authors' focus on local processes of ethical deliberation characterized by diverse norms and concerns illustrates how important ethnography can be in helping to tease out the vast range of community economies that might emerge and their different effects in terms of socio-ecological exploitation.

\section{Toward a non-capitalist political ecology, or "moving beyond the capitalist beast"}

With this collection, we hope to advance scholarship and activism for non-capitalist political ecologies and to bring the ideas of Gibson-Graham to the attention of anthropologists. We are particularly pleased to present these articles in the Journal of Political Ecology because scholars are just beginning to explore the potential synergies between the diverse economies project and political ecological work in anthropology and geography (see, for example, Gibson-Graham 2011; Gibson-Graham and Roelvink 2010; St. Martin 2006, 2009). Political ecology provides perhaps the most holistic framework for analyzing injustice, and its insistence on the constitutive role of the environment in history is critical for analyzing and supporting noncapitalist practices. Surprisingly, while the environment was implicit in much of Gibson-Graham's early work-present in the ethical referents that they suggest for community economies and occasionally mentioned in relation to different strategies for producing and procuring goods-it was never the focus of analysis. We think that increased focus on the ecological is essential because "the exploitation of humans and the exploitation of nature are fundamentally interconnected" (Burke 2012: 114), and because there is too much potential for community economies to embody environmentalist platitudes while re-creating ecological injustices at other scales (Bryant and Goodman 2004; Heynen 2003; Smith and Stenning 2006).

At the same time, the community economies work can infuse political ecology (and anthropology) with a productive, affirmative, world-making approach that seems largely absent. Despite early influences from cultural ecology and research on the commons, political ecology has moved away from considerations of non-capitalist economies, or at least from an analysis of capitalism and non-capitalism as co-eval. Political ecologists focused on diagnosing and exposing injustice have too often fallen into the trap of capitalocentric critique and other cynical apriorisms. The diverse economies framework and the analytical stance of political possibility embodied in studies of overdetermination and performativity might help re-connect political ecology with these earlier roots, as well as with contemporary 'alternative economies' activism. This will grant more power to political ecologists' recent calls to politicize socio-ecological futures (Swyngedouw 2007). To complement political ecology's traditional focus on the production of unevenness, we can imagine a burgeoning current of research focused on the production of evenness, inclusion, cooperation, and nonexploitation. ${ }^{6}$

Now, more than ever, we need intellectual engagement with the "relations between human society, viewed in its bio-cultural-political complexity, and a significantly humanized nature" (Greenberg and Park

\footnotetext{
${ }^{5}$ This is congruent with Gibson-Graham's vision of the diverse economies intervention. "We are not overly concerned with the chaotic and noncomprehensive aspects of this language experiment, as our objective is not to produce a finished and coherent template that maps economy 'as it really is' and presents (to the converted or suggestible) a ready-made alternative economy" (2006: 60). We believe that the long-term, close ethnographic engagement of anthropologists might be particularly efficacious in illuminating local politics and epistemologies around diverse economies frameworks.

6 This would be analogous to Eric Wolf's call for the study of "peacefare" as a necessary corollary to the study of "warfare" (Fox 1995; Wolf 1987).
} 
1994). Humans have become a force for planetary change, giving rise to a new geological epoch, the Anthropocene, defined by the "human domination of Earth's ecosystems" (Vitousek et al. 1997) and humangenerated changes "so pervasive and profound that they rival the great forces of Nature and are pushing the Earth into planetary terra incognita" (Steffen, Crutzen and McNeill 2007: 614). How do we proceed under such pressing conditions? How might we best conceptualize and situate ourselves in relation to nature and political economy in order to conceive of and create new political ecologies? What seems certain is that proceeding in relation to dominant understandings of ecology and economy-whether to critique, oppose, or reform - is a fraught proposition.

We hope that this collection can contribute to a project of excavating possibility, to a "practical political ecology of alternative development" (Rocheleau 2008: 717). Following Gibson-Graham, we join with the growing chorus of scholars endeavoring to illuminate and expand the submerged and disavowed values, beliefs, and practices that can move us towards a new horizon, towards a non-capitalist, noncapitalocentric political ecology. At the dawn of the Anthropocene, it has never been more urgent that we join with our research subjects who, like all of us, already desire non-capitalism and know that "another world is possible".

\section{Non-capitalist political ecologies, edited by Brian J. Burke and Boone Shear}

1. Sarah Lyon - Fair Trade Towns USA: growing the market within a diverse economy

2. Noor Johnson - Thinking through affect: Inuit knowledge on the tundra and in global environmental politics

3. Cristina Grasseni - Seeds of trust. Italy's Gruppi di Acquisto Solidale (Solidarity Purchase Groups)

4. Boone W. Shear - Making the green economy: politics, desire, and economic possibility

5. Stephen Healy - The biopolitics of community economies in the era of the Anthropocene

\section{References}

Badiou, A. 2010. The idea of communism. In C. Douzinas and S. Zizek (eds.) The idea of communism. London: Verso. Pp. 1-14.

Blaikie, P. and H.C. Brookfield. 1987. Land degradation and society. London: Methuen.

Bryant, R.L. and M.K. Goodman. 2004. Consuming narratives: the political ecology of 'alternative' consumption. Transactions of the Institute of British Geographers 29(3): 344-366.

Burke, B.J. 2012. Transforming power in Amazonian extractivism: historical exploitation, contemporary 'fair trade', and new possibilities for indigenous cooperatives and conservation. Journal of Political Ecology 19: 114-126.

Burke, B.J. and B. Shear. 2013. Beyond critique: anthropology of and for non-capitalism. Anthropology News 54(1-2): 17, 21.

Cameron, J. 2007. Teaching a politics of hope and possibility. Invited keynote presentation to SocCon 2007: National Conference of New Zealand Social Science Teachers.

Cameron, J., C. Manhood and J. Pomfrett. 2010. Growing the community of community gardens: research contributions. Paper submitted to the Community Garden Conference, Canberra.

Chatterton, P., S. Hodkinson and J. Pickerill. 2010. Beyond scholar activism: making strategic interventions inside and outside the neoliberal university. ACME: An International E-Journal for Critical Geographies 9(2): 245-275.

Clifford, J. and G. Marcus. 1986. Writing culture: the poetics and politics of ethnography. Berkeley: University of California Press.

Cornwell, J. 2013. Who's on the map? Anthropology News. 54(1-2): 20-21. 
Davis, M. 1999. Ecology of fear: Los Angeles and the imagination of disaster. New York: Vintage Books.

Day, R.J.F. 2005. Gramsci is dead: anarchist currents in the newest social movements. London: Pluto Press.

Donham, D.L. 1999. History, power, ideology: central issues in Marxism and anthropology. Berkeley: University of California Press. 2001. Thinking temporally or modernizing anthropology. American Anthropologist 103(1): 134-149.

Escobar, A. 1999. After nature: steps to an antiessentialist political ecology. Current Anthropology 40(1): 130.

Farmer, P. 1996. On suffering and structural violence: a view from below. Daedalus 125(1): 261-283.

Ferguson, J. 2010. The uses of neoliberalism. Antipode 41(1): 166-184.

Forsyth, T.J. 2008. Political ecology and the epistemology of social justice. Geoforum 39: 756-764.

Foster, J.B. 2009. The ecological revolution: making peace with the planet. New York: Monthly Review Press.

Fox, R.G. 1995. Cultural dis-integration and the invention of new peace-fares. In J. Schneider and R. Rapp (eds.) Articulating hidden histories: exploring the influence of Eric R. Wolf. Berkeley: University of California Press. Pp. 275-288.

Geertz, C. 1973. Religion as a cultural system. In The interpretation of cultures. New York: Basic Books. Pp. 87-125.

Gibson-Graham, J.K. 1996. The end of capitalism (as we knew it): a feminist critique of political economy. Minneapolis: University of Minnesota Press. . 2006. A postcapitalist politics. Minneapolis: University of Minnesota Press. . 2008. Diverse economies: performative practices for other worlds. Progress in Human Geography 32(5): 613-632.

2011. A feminist project of belonging for the Anthropocene. Gender, Place and Culture 18(1): 1-21.

Gibson-Graham, J.K. and G. Roelvink. 2010. An economic ethics for the Anthropocene. Antipode 41(1): 320346.

Gibson-Graham, J.K., J. Cameron and S. Healy. 2013. Take back the economy: an ethical guide for transforming our communities. Minneapolis: University of Minnesota Press.

Gramsci, A. 1971. The prison notebooks. Q. Hoare and G.N. Smith (eds. and transl.). New York: International Publishers.

Grasseni, C. 2014. Seeds of trust. Italy's Gruppi di Acquisto Solidale (Solidarity Purchase Groups). Journal of Political Ecology 21: 178-192.

Greenberg, J.B. 1981. Santiago's sword: Chatino peasant religion and economics. Berkeley: University of California Press.

. 1995. Capital, ritual, and boundaries of the closed corporate community. In J. Schneider and R. Rapp (eds.) Articulating hidden histories: exploring the influence of Eric R. Wolf. Berkeley: University of California Press. Pp. 67-81.

. 1997. A political ecology of structural-adjustment policies: the case of the Dominican Republic. Culture and Agriculture 19(3): 85-93.

Greenberg, J.B. and T.K. Park. 1994. Political ecology. Journal of Political Ecology 1: 1-12.

Harrington, B. 2010. Parsing performativity. Economic Sociology blog.

Harvey, D. 2003. The new imperialism. Oxford: Oxford University Press

Healy, S. 2014. The biopolitics of community economies in the era of the Anthropocene. Journal of Political Ecology 21: 210-221.

Heynen, N.C. 2003. The scalar production of injustice within the urban forest. Antipode 35(5): 980-998.

Johnson, N. 2014. Thinking through affect: Inuit knowledge on the tundra and in global environmental politics. Journal of Political Ecology 21: 161-177.

Law, J. and Urry, J. 2004. Enacting the social. Economy and Society 33(3): 390-410. 
Lee, S. and W-M. Roth. 2001. How ditch and drain become a healthy creek: re-presentations, translations and agency during the re/design of a watershed. Social Studies of Science 31(3): 315-356.

Lyon, S. 2011. Coffee and community: Maya farmers and fair-trade markets. Boulder: University Press of Colorado.

Lyon, S. 2014. Fair Trade Towns USA: growing the market within a diverse economy. Journal of Political Ecology 21: 145-160.

Martinez-Alier J., Anguelovski I., Bond P., Del Bene D., Demaria F., Gerber J.-F., Greyl L., Haas W., Healy H., Marín-Burgos V., Ojo G., Porto M., Rijnhout L., Rodríguez-Labajos B., Spangenberg J., Temper L., Warlenius R. and I. Yánez. 2014. Between activism and science: grassroots concepts for sustainability coined by Environmental Justice Organizations. Journal of Political Ecology 21: 19-60.

Nguyen, V-K. and K. Peschard. 2003. Anthropology, inequality, and disease. Annual Review of Anthropology. 32: 447-474.

Peluso, N.L. and M.J. Watts (eds.). 2001. Violent environments. Ithaca: Cornell University Press.

Resnick, S. and R.D. Wolff. 1987. Knowledge and class: a Marxian critique of political economy. Chicago: University of Chicago Press.

2013. On overdetermination and Althusser: our response to Silverman and Park. Rethinking Marxism 25(3): 341-349.

Robben, A.C.G.M. 1989. Sons of the sea goddess: economic practice and discursive conflict in Brazil. New York: Columbia University Press.

Rocheleau, D. 2008. Political ecology in the key of policy: from chains of explanation to webs of relation. Geoforum 39: 716-727.

Roseberry, W. 1989. Anthropologies and histories: essays in culture, history, and political economy. New Brunswick, NJ: Rutgers University Press.

1998. Social fields and cultural encounters. In G.M. Joseph, C.C. LeGrand, and R.D. Salvatore (eds.) Close encounters of empire: writing the cultural history of US-Latin American relations. Durham: Duke University Press. Pp. 515-524.

St. Martin, K. 2006. The impact of 'community' on fisheries management in the U.S. Northeast. Geoforum 37(2): 169-184.

2009. Toward a cartography of the commons: constituting the political and economic possibilities of place. Professional Geographer 61(4): 493-507.

Shear, B.W. 2014. Making the green economy: politics, desire, and economic possibility. Journal of Political Ecology 21: 193-209.

Shear, B.W. and V. Lyon-Callo. 2013. Kalamazoo's promise: exploring the violence of economic development. City and Society 25(1): 70-91.

Smith, A. and A.C. Stenning. 2006. Beyond household economies: articulations and spaces of economic practice in postsocialism. Progress in Human Geography 30(2): 190-213.

Steffen, W., P.J. Crutzen and J.R. McNeil. 2007. The Anthropocene: are humans now overwhelming the great forces of nature? Ambio 36(8): 614-621.

Swyngedouw, E. 2007. Impossible 'sustainability' and the post-political condition. In D. Gibbs and R. Krueger (eds). The sustainable development paradox: urban political economy in the United States and Europe. New York: The Guilford Press. Pp. 13-40.

2011. Whose environment? The end of nature, climate change, and the process of post-politicization. Ambiente y Sociedade 14(2): 69-87.

Trainer, F.E. 1995. The Conserver Society: alternatives for sustainability. London: Zed.

Vitousek, P.M., H.A. Mooney, J. Lubchenco, and J.M. Milillo. 1997. Human domination of Earth's ecosystems. Science 277 (5325): 494-499.

West, P. 2010. Making the market: specialty coffee, generational pitches, and Papua New Guinea. Antipode 42(3): 690-718. 
Wolf, E.R. 1982. Europe and the people without history. Berkeley: University of California Press. 1987. Cycles of violence: The anthropology of war and peace. In Kenneth Moore (ed.) Waymarks: the Notre Dame inaugural lectures in anthropology. Notre Dame: University of Notre Dame Press. Pp. 127-150.

Yates, M.D. 2008. The injuries of class. Monthly Review 59(8): 1-10.

Zizek, S. 2004. What Rumsfeld doesn't know that he knows about Abu Ghraib. In these times. May 21. http://inthesetimes.com/article/747/what_rumsfeld_doesn_know that he_knows about_abu_ghraib/ . 2007. Censorship today: violence or ecology as a new opium of the masses.

http://www.lacan.com/zizecology2.htm 